Cahiers $d u$ MONDE RUSSE

\section{Cahiers du monde russe}

Russie - Empire russe - Union soviétique et États indépendants

$46 / 1-2 \mid 2005$

La Russie vers 1550

\title{
Political thinking in Moscow in the sixteenth and
}

seventeenth centuries

Peresvetov, križaniç and the grammatisation of knowledge

\section{STEFAN SCHNECK}

\section{CpenEdition}

Journals

Édition électronique

URL : https://journals.openedition.org/monderusse/8808

DOI : $10.4000 /$ monderusse. 8808

ISSN : $1777-5388$

Éditeur

Éditions de l'EHESS

Édition imprimée

Date de publication : 1 janvier 2005

Pagination : $327-336$

ISBN : 2-7132-2055-6

ISSN : $1252-6576$

Référence électronique

STEFAN SCHNECK, "Political thinking in Moscow in the sixteenth and seventeenth centuries », Cahiers du monde russe [En ligne], 46/1-2 | 2005, mis en ligne le 01 janvier 2007, consulté le 04 septembre 2022. URL : http://journals.openedition.org/monderusse/8808 ; DOI : https://doi.org/ $10.4000 /$ monderusse. 8808 


\section{CAIR N}

chercher : repérer : avancer

Cet article est disponible en ligne à l'adresse :

http://www.cairn.info/article.php?ID REVUE=CMR\&ID NUMPUBLIE=CMR 461\&ID ARTICLE=CMR 4610327

Political thinking in Moscow in the sixteenth and seventeenth centuries. Peresvetov, krizaniç and the grammatisation of knowledge

par STEFAN SCHNECK

\section{| Editions de l'EHESS | Cahiers du monde russe}

\section{5/1-2 - Vol 46}

ISSN 1252-6576 | ISBN 2713220556 | pages 327 à 336

Pour citer cet article :

- SCHNECK S., Political thinking in Moscow in the sixteenth and seventeenth centuries. Peresvetov, krizaniç and the grammatisation of knowledge, Cahiers du monde russe 2005/1-2, Vol 46, p. 327-336.

Distribution électronique Cairn pour les Editions de l'EHESS.

(C) Editions de l'EHESS. Tous droits réservés pour tous pays.

La reproduction ou représentation de cet article, notamment par photocopie, n'est autorisée que dans les limites des conditions générales d'utilisation du site ou, le cas échéant, des conditions générales de la licence souscrite par votre établissement. Toute autre reproduction ou représentation, en tout ou partie, sous quelque forme et de quelque manière que ce soit, est interdite sauf accord préalable et écrit de l'éditeur, en dehors des cas prévus par la législation en vigueur en France. Il est précisé que son stockage dans une base de données est également interdit. 


\title{
POLITICAL THINKING IN MOSCOW IN THE SIXTEENTH AND SEVENTEENTH CENTURIES
}

\author{
Peresvetov, Križanić \\ and the grammatisation of knowledge
}

In the middle of the sixteenth century in the so called "Great Supplication" to Ivan IV Ivan Peresvetov puts forward his ideas of a just, well-ordered State in a sententia-like comparison: "Like a horse without bridle so is an empire without dread." $\mathrm{He}$ then makes some concrete proposals for the improvement of the Muscovite State and underlines his propositions with numerous examples from recent history and references to the Bible, which take no more than 12 pages in modern font.

More than hundred years later Juraj Križanić writes in his Politika - which was prepared for the tsar Aleksei Mikhailovich and his innermost circle - about the essence of the political the very abstract formula: "political things - this means the matters and deeds of the tsar, the tsardom and the people." $\mathrm{He}$ then explains, in detail, his definition on the following 260 (!) pages, filling them with concrete content. His examples and citations stem from sources, which can be called "the canon of the European scholars" of his time, stretching from the Old Testament over Cicero up to Lipsius.

On the following pages I would like to show, that the glaring differences between the argumentation of Peresvetov and Križanić must be understood not only as personal author defined idiosyncrasies such as their different educations, worldviews and biographies. The differences are closely linked to deep changes in the

\footnotetext{
1. D. S. Likhachev, ed., Sochineniia I. Peresvetova (M.-L., 1956): 189.

2. Iurii Krizhanich, Politika, N. Tikhomirov, ed. (M., 1965): 371 [hereafter Politika].
} 
mode of argumentation at the court of the tsar in Moscow from the sixteenth to the seventeenth century. The authors try to convince in different ways because at the court of the tsar the idea of a well-built argumentation in the sixteenth century was fundamentally different from what it was in the seventeenth century.

\section{Two worlds - two languages}

The first clues about the different kind of worlds addressed by each of the authors are the form, language and content of their works. The "Great Supplication" of Peresvetov fits very well into the literary and political context of his time. As regards construction, it is a thoroughly heterogeneous work, consisting of a number of textpieces, very different both in style and content, which are cobbled together as a new entity and can therefore be referred to as a coherent text only in a very loose sense of the word. ${ }^{3}$ Some elements tend to use the rules and language of religious tradition, some others quote Apocrypha and sententiae, which are typical for oral language. The dependence of Peresvetov's works on Russian or Western-European traditions of political thinking is more difficult to prove, because it can be traced only indirectly. ${ }^{4}$ But to understand the construction of the argument, the question of its genesis and affiliation is irrelevant anyway.

The Politika of Križanić, meanwhile, is a monograph in the modern sense: it has a beginning, reflects inner construction (even making references within the text!) and has the obligatory table of contents. It deals exhaustively with all aspects of a given theme according to a thought-out plan. Križanić uses specialized terminology. Metaphorical or sententiae-like formulations are seldom used and only for specific purposes. Usually Križanić explains them directly afterwards, to leave no room for misunderstanding. 5

\section{Well-built argumentation — additive or constructive?}

Particularly interesting and typical for its time is the form of argumentation of the authors. Peresvetov uses for his purpose the traditional form of a supplication even though the internal structure is entirely narrative. The narration stages actors with different roles and frequently uses direct speech. The usual, stereotyped, greeting formula is replaced by a reference to the scholarly sources (Greek philosophers and Roman doctors) of his treatise. His understanding of an orthodox State, who knows how to defend himself, is embedded in the story as short figural sententiae: "The

3. W. Philipp, Ivan Peresvetov und seine Schriften zur Erneuerung des Moskauer Reiches (Königsberg, 1935).

4. A. A. Zimin, I. S. Peresvetov i ego sovremenniki: Ocherki po istorii russkoi obshchestvennopoliticheskoi mysli serediny XVI veka (M., 1958); A. Danti, "Ivan Peresvetov: Osservazioni e proposte," Ricerche Slavistiche, 12 (1964): 3-63.

5. Politika: 648, 650, 572 . 
rich loves quietness. But the fighter you always have to train like a hawk, cheer up his heart and don't let any harm affect him."6 Peresvetov then illustrates those sententiae with historical experience: "The Greeks were tired to stand strong for Christian faith against the infidels and now they have to protect unwillingly the Muslim faith against its enemies." 7 The just and good State is presented in religious terms: "Justice is for God the joy of his heart, for the tsar it's wisdom."8 Concrete experience illustrates the content of the terms. In this case the Turkish sultan serves as example: "[Sultan Mehmet] might be an infidel tsar, he did nevertheless what pleases God: he brought great wisdom and justice to his empire, sent his faithful judges throughout his empire and gave them wages from the Treasury, with which they can live from year to year."9 To convince his readers, Peresvetov relies on redundancy and obviousness. Christian tradition, expounded in very general terms, is illustrated right away and briefly explained. Arguments are put in a line by the author and his copiers in an additive manner.

Križanić's writing is very different. ${ }^{10}$ His text has a vertical dimension throughout. It is abstract, using three core concepts - blessings, power and wisdom - to describe the State. Their meaning is not immediately clear to the reader and can only be construed through a careful reading of the text. The purpose of the argumentation is not irrefutable evidence, but critical analysis of the selfevident, and elucidation of the more elusive concepts. This is as true for the State as a whole as for the single concepts which determine it. Let's take the example of "wisdom" (mudrost'). Križanić develops in a very complicated manner the meaning of wisdom from the construction of "reason" (razum) as specific human quality:

Speechless animals have, from birth on, clothing - fur or feathers, they have weapons - horns, teeth, claws; and they know without teachers the things, which they need to survive [...]. Only man is born naked and without weapons. He can't swim and knows nothing. He has no clothing, he has no weapons, he has not the things he needs to survive, if he doesn't get them through his work and sweat; he knows nothing, if he doesn't study. But from the very birth he has two gifts, which speechless animals don't have: the reason to learn wisdom, and hands to make wise and artful things. ${ }^{11}$

The following definition of "wisdom" as learning can be derived from the argumentation by the reader only with the help of an extensive knowledge of the

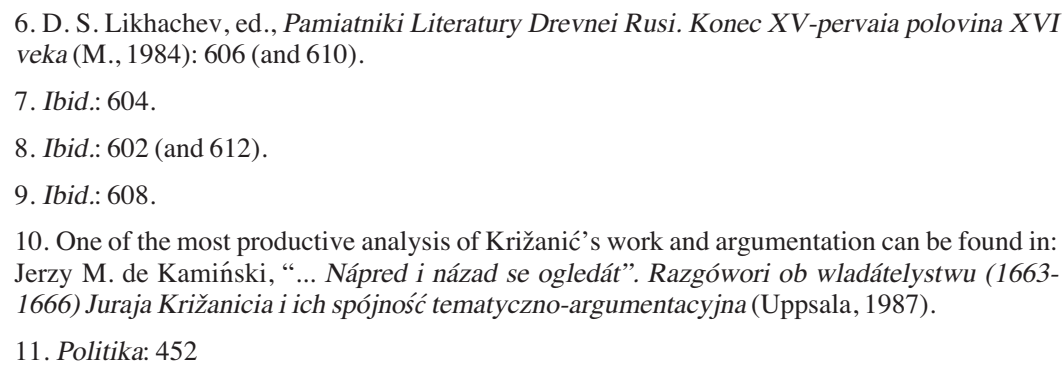

10. One of the most productive analysis of Križanić's work and argumentation can be found in: Jerzy M. de Kamiński, “... Nápred i názad se ogledát”. Razgówori ob wladátelystwu (16631666) Juraja Križanicia i ich spójność tematyczno-argumentacyjna (Uppsala, 1987).

11. Politika: 452 
canon of a humanistic historian. Only after three pages of argument, built step-bystep, can we read the practical consequence:

It means, that we have also to learn and hope, that under the good governance of the blessed Tsar and Grand Duke Aleksei Mikhailovich we shall put away the mould of old savagery, learn sciences, build a better relationship between people and realise a more happy being.

This careful construction of argument by Križanić has far-reaching implications, as we shall see later. Peresvetov, on the other hand, feels no need to explain the structure of his work. Neither does he have to make reference to his sources, the Bible or the Tale of Iskander. It is understood by him and his readers, that he is part of this literary tradition. His own work will be dealt with in the same - very free and selective - manner depending on the mercy of the copyist. On the contrary, Križanić writes down what he thinks about his work, or his position in literary tradition, and never forgets his readers. Even the words he uses are not taken for granted, nor the structure of his work:

Jeremiah says: "Let not the wise man glory in his wisdom, neither let the mighty man glory in his might, let not the rich man glory in his riches" [9, 23] [...] That is why we divide this work in three parts and will tell about the wealth, the power and the wisdom of the tsar. ${ }^{12}$

He then goes on to explain these three crucial concepts. When he comes to wisdom, he formulates his step-by-step construction explicitly: "As the third part of these advices to the people is about wisdom, we have to explain first of all shortly, what wisdom, knowledge and philosophy are."13

His way of quoting is also revealing: his sources are nearly always named explicitly. The ideas (or authority) of others are not essential to his work, but merely a helpful element in his own intellectual construction - they are used instrumentally and consciously, defining the status of the idea as another person's, borrowed only to clarify a particular point in the course of ideas. ${ }^{14}$ When he uses already internalised arguments (e.g. Aristotle), Križanić - consciously or unconsciously - does not refer to his source explicitly. ${ }^{15}$ Thus heterogeneous elements, like scholastic and mercantilist pieces of reasoning, can be brought together to write a completely new text. This method and his critical relationship to his own sources has a strong influence on the structure of Križanić work: he has carefully devised a plan of the political, as we can see from his hand-drawn sketches in the original manuscript.
12. Ibid.: 374 .
13. Ibid.: 456 .
14. Ibid.: 568,649 . The indications are often very questionable.
15. Ibid.: 458 . 


\section{Križanić and the grammatisation of knowledge}

For his description of the political, Križanić uses a kind of universal model for argumentation, which was not known in Moscow at the time of Peresvetov: grammar. Typical for grammar as a method, as I understand it, is to divide knowledge into its smallest units, to put them in relation on the basis of certain functions and to build up a hierarchical system of knowledge, which is linked by rules of interdependence. Let's have a look at this method in Križanić description of the State. Križanić writes:

We will talk about three things, [...] in which the world sees its own happiness I mean wealth, power and wisdom [...]. The wealth of the ruler does not so much consist in his gold- and silver-treasury as in the wealth of the population. [...] The power is not so much in the size of the empire or strength of their defence, as in good laws. ${ }^{16}$

Obviously, these three concepts (and the corresponding parts of the book) imply something similar to the economic, military and scientific spheres of society. But, as some terms (e.g. "wealth" [blago], "wisdom") have ambiguous meanings, sometimes linked to the religious sphere, the concrete meaning of the terms in Križanić text becomes clear only after the argumentation is completed. He divides all three basic parts of the State into smaller units, which in turn will be analysed. Thus Križanić builds up a strictly hierarchical system, from the very bottom to the top, from the "atoms" of the political, through the middle-spheres of the State to the whole - the "Politika." Križanić builds a grammar of the political.

A good example of this "grammatical method" is the construction of the concept of "wealth." Wealth is divided by Križanić into wealth of the people and wealth of the State. Križanić then divides this sphere further into different types of wealth (property, money) and different ways of acquiring wealth (trade, craftsmanship, agriculture and metallurgy). He goes further and further into details: good and bad ways to raise taxes, importance of metals, of trade routes, paper-mills, seeds, production of tar, the right way of sawing, free sale of tobacco, growing grapevines, and how to exploit mines. After this chapter we know for certain what he has in mind under the concept of "wealth": it is, indeed, very close to what we understand today as the economical sphere.

The most clear-cut segmentation we find in the second part about power: seven elements - fortifications, weapons, army organisation, personnel, leaders, speeches/names/costume and wages/honours. No doubt - talking about power, Križanić has in mind the military. And the division goes on. Weapons for example are divided into beating, cutting, piercing, shooting, siege and defending weapons. The defending weapons are for example the shield, the knight's breast-plate, the lynx's fur, the trench and the tower. This way Križanić works out a grammar of the political in four steps, from the most abstract categories, through power and

16. Ibid:: 374-375 
defending weapons, down to the smallest elements of the State, like e.g. "elbow schooner."

Of the three components of the State, it is the concept of wisdom which requires the most detailed and difficult segmentation. Wisdom is divided into wisdom, knowledge and philosophy:

Wisdom is knowledge of the most important and highest things. That is: of God, of heaven, of earth, of the habits of the people [...]. Knowledge - this is understanding the reasons of things [...]. Philosophy or love for wisdom - this is "striving for wisdom." 17

The argumentation goes on in a very scholastic/Aristotelian manner: "There are four main causes: the creator, the material, the form and the end. Minor causes are: the tool, the circumstances and others." ${ }^{18}$ In the case of wisdom, Križanić shows the result of its ongoing analysis, of its segmentation into basic components in a fascinating sketch, which illustrates perfectly the essence of his grammatical method: total description by segmentation of an empirical, homogeneous, but functionally distinctive, material and its organisation in a strictly hierarchical system.

Križanić uses grammar as method also in other parts of his corpus. In his original grammar of Slavic languages he presents his own "grammatical method" very concisely:

The dot is the smallest part of the language; with dots you build lines, with lines letters as $\mathrm{a}, \mathrm{b}, \mathrm{v}, \mathrm{g}$. With letters syllables [...]. With syllables words [...]. With words sentences $[\ldots]$. With sentences languages $[\ldots]$. And from languages, groups of languages [...]. Of Slavic languages we have six [...] Russian, Polish, Czech, Croat, Serb and Bulgarian. ${ }^{19}$

This method of segmentation and construction of a new hierarchical order can be found in seventeenth-century Europe in nearly all intellectual disciplines within small distances of time and applied to different degrees. Grammar finds naturally its first and most complete form in linguistics. The work on a Russian grammar can be understood as a direct answer to the challenge of the Catholic expansion in the disputed lands between Warsaw and Moscow at the end of the sixteenth century. In a polemical climax, Piotr Skarga reproached the Orthodox their lack of knowledge: without a grammar, Russian would never be a holy language. Learning from the enemy, the first eastern-Slavic Orthodox grammars are published at the end of the sixteenth century (1591, Adelphotes and 1596, the Grammar by Zizanij) by the Orthodox schools (bratskie shkoly) organized on the model of Jesuit colleges.

17. Ibid.: 457.

18. Ibid.: 458 .

19. J. Hamm, ed., Juraj Križanić. Objasněnije vivodno o pismě slověnskom (Sabrana Dela, Knjiga 1) (Zagreb, 1983): 5-5 . 
As a model for Moscow, the publication of Smotritskii's grammar (1619 in Kiev, 1648 in Moscow) is of utmost importance. Typically, these linguistic grammars are introduced by pedagogical questions and very analytical step-by-step answers: "What is Grammar? [...] How many parts are there in Grammar? Four : Orthography, Etymology, Syntax and Prosody" etc. In music also, we have similarly constructed grammars, partly close to foreign models, ${ }^{20}$ but some of them autochtone works. ${ }^{21}$ The opening questions are similar: "What is music? [...] How many types of music are there? Two, one with the voice, the other with instruments." 22 In Rhetoric ${ }^{23}$ and Mathematics ${ }^{24}$ we find the same stereotyped forms at the beginning. Indeed, the inner structure itself changes fundamentally, for instance in the case of handbooks of mathematical exercises. Whereas traditional Arithmetic ${ }^{25}$ lumps together all exercises dealing with a given profession, e.g. fishselling, Magnitskii's Arifmetika arranges them systematically, according to mathematical categories like geometry or algebra. A similar process of reorganisation of knowledge in the seventeenth century can also be found in medicine (treatise "about human nature,"26 translation of Vesalius's Anatomy in the middle of the century) and also in more abstract types of knowledge such as the internal order of books (e.g. table of contents) and libraries (e.g. catalogues) ${ }^{27}$.

\section{The fate of grammar}

Yet, how could a genre like grammar, which comes from a specific linguistic context, find its way into all intellectual disciplines in seventeenth-century Muscovy? Is this the best way to understand reality, is it one of the famous tricks of rationality? As the main narrative for the history of science, the triumph of rationality has been put aside a long time ago. Indeed, the knowledge of grammar in the seventeenth century does not necessarily improve the quality of argumentation, as showed with magnificent clarity by Simeon Polotskii when he accused Nikita Dobrynin of ignorance because he had not studied grammar. He explains to him that double negation in Russian means "yes" - ignoring this being obviously a grave error from the point of view of the learned man.

20. S. V. Smolenskii, ed., Musikiiskaia grammatika Nikolaia Diletskago (SPb., OLDP, 1910).

21. N. P. Parfent'ev, ed., Aleksandr Mezenets i prochie. Izveshchenija ... zhelaiushchim uchitisia peniiu, 1670 g. (Cheliabinsk, 1996).

22. S. V. Smolenskii, op. cit., p. 11.

23. R. Lachmann, ed., Die Makarij Rhetorik (Köln, 1980); Stefan Iavorskii, Ritoricheskaia ruka (SPb., OLDP, 1878).

24. L. F. Magnitskii, Arifmetika (M., 1703).

25. e.g. Arithmetic (BAN 17.6.24).

26. N. K. Gavriushin, "Drevnerusskii traktat 'O chelovechestem estestve"”, in R. A. Simonov, ed., Estestvenno-nauchnye predstavleniia Drevnei Rusi (M., 1988): 220-227.

27. M. I. Slukhovskii, Russkaia biblioteka XVI-XVII VV. (M., 1973). 
Grammar is probably not always the most adequate system to describe reality. Or should we consider the success of grammar as a sign that "the western way" found "at last" its way to Russia? We must remember that grammar was not always understood as typically western; besides, authors of grammars often tried to hide their western provenance. Both concepts, rationalisation and westernisation alike, are involved in certain aspects of the complex process which takes place in the area of knowledge and proto-sciences in Russia in the seventeenth century. But, at the same time, focusing on them may distract our attention from the specific mechanisms, problems and also curiosities of this process. The concept of grammar has many advantages in that respect. It is taken directly from the sources, it includes different spheres of knowledge and at the same time keeps at safe distance from the narratives of rationalisation and westernisation, which inevitably produce the worn-out description of backward Russia - belated and imperfect copy of its western neighbour.

As far as my studies allow me to undertake a general description of this grammatisation of Russian culture, the crucial channel for this model was pedagogy in the brother schools and the intellectual spaces they created, which were relatively free from everyday influence. Here grammar could develop and find its place into the future Moscow elite. Karion Istomin wrote in 1694: "Grammar teaches us to know." ${ }^{28}$ Indeed, ranking first in the timetable, before all other subjects of the seven artes liberales, pupils of orthodox brotherhood schools and of Jesuits alike learned grammar, which meant the segmentation of language, the learning by heart of paradigms and rules. Traditionally languages and writing were taught without involving abstract concepts, simply by reading and copying parts of the Holy Scripture. To the new generation in brother schools, a well-built argumentation looked different than to their fathers. It was not any longer the repetition of familiar elements, but the bringing into play of rules which had basically a functional rationale - in short: which was similar to the model of the grammar.

The reason for the fundamental differences between our two authors does not stem from personal idiosyncrasies, but from the general cultural background of the tsar's court in sixteenth- and seventeenth-century Moscow. The tendency to oral language of Peresvetov, contrasting with Križanić's specialized terminology, suggests the following presupposition: while the tsar and his immediate surrounding in the sixteenth century were still open to a culture based on popular and religious parameters, the seventeenth century witnesses the dominance of an intellectual culture independent from popular and religious tradition. In this elite culture, new ways of argumentation appear, which are bound to a new milieu of intellectuals. The existence of this new milieu at the court of Aleksei Mikhailovich is the basis for the later development of Russia within the plans of Peter the Great.

28. Karion Istomin, Polis (1694), GIM, Chud. 301, 1. 276, in: Karion Istomin, Kniga liubvi znak $v$ chesten brak, L. I. Sazonova, ed. (M., 1989): 57. 
This new milieu is connected to a modern intellectual culture, the principal parameters of which are still ours today.

\section{Humboldt-Universität zu Berlin}

StefanSchneck@gmx.de 